\title{
PERSALINAN PADA IBU DENGAN RIWAYAT KEKURANGAN ENERGI KRONIS
}

\section{DELIVERY IN A MOTHER WITH A HISTORY OF CHRONIC ENERGY LACK OF}

\author{
Widya Maya Ningrum ${ }^{1 *}$, Erni Puspitasari ${ }^{2}$ \\ Universitas Galuh, Indonesia \\ Jalan R.E Martadinata No.150 Ciamis 46213, Indonesia \\ *E-mail corresponding: widyamayaningrum@gmail.com \\ (Diterima: September 2021; disetujui Oktober 2021; dipublish November 2021)
}

\begin{abstract}
ABSTRAK
Ibu hamil yang mengalami KEK akan mengalami kekurangan gizi, tubuh mudah lelah, pucat, lemas, dan mengalami kesulitan salah satunya dalam proses persalinan. Pengaruh KEK terhadap proses persalinan dapat mengakibatkan persalinan sulit dan lama, persalinan sebelum waktunya (prematur), pendarahan setelah persalinan, serta persalinan dengan operasi. Puskesmas Sadananya data ibu hamil yang mengalami KEK sebanyak 70 orang $(9,49 \%)$ dan berlanjut ke penyulit lainnya yaitu mengalami Abortus 5 0rang (3,5\%), BBLR 9 bayi (6,3\%). Jenis Penelitian ini merupakan penelitian deskriptif. Populasi dalam penelitian ini adalah seluruh ibu bersalin dengan riwayat KEK pada masa kehamilan di Wilayah Kerja Puskesmas Sadananya Kabupaten Ciamis Tahun 2019 sebanyak 70, Teknik pengambilan sempel mengunakan Simple Random Sampling. Analisa dalam penelitian ini adalah Univariat. Hasil penelitian menunjukan sebanyak 3 oang mengalami persalinan sebelum waktunya $(4,3 \%), 1$ orang mengalami perdarahan paska salin disebebkan atonia uteri $(1,4 \%)$, dan 8 orang proses persalinan dengan Operasi (SC) $(11,4 \%)$. Kesimpulan dari penelitian ini adalah Ibu hamil dengan riwayat KEK mengalami penyulit persalinan, meskipun secara jumlah tidak terlalu signifikan, namun hal ini tentunya tetap harus menjadi perhatian khususnya bagaimana bisa mencegah ibu hamil untuk tidak mengalami anemia, dan apabila sudah terjadi sebagai seorang bidan tentunya harus dapat mendeteksi penyulit yang akan terjadi denganmelakukan penapisan awal persalinan
\end{abstract}

Kata kunci : Persalinan, Kekurangan Energi Kronis (KEK)

\begin{abstract}
Pregnant women who experience KEK will experience malnutrition, body easily tired, pale, weak, and experience difficulties, one of which is in the delivery process. The effect of KEK on the labor process can result in difficult and prolonged labor, preterm labor, bleeding after delivery, and delivery by surgery. Puskesmas Sadananya data on pregnant women who experience KEK as many as 70 people $(9.49 \%)$ and continue to other complications, namely experiencing 5 0rang abortion (3.5\%), LBW 9 babies (6.3\%). This type of research is a descriptive study. The population in this study were all 70 women who gave birth with a history of KEK during pregnancy in the Work Area of the Sadananya Health Center, Ciamis Regency in 2019, the sampling technique used was Simple Random Sampling. The analysis in this research is Univariate. The results showed as many as 3 people experienced premature labor $(4.3 \%), 1 \%$ experienced post-saline bleeding due to uterine atony (1.4\%), and 8 people went into labor by surgery (11.4\%). The conclusion of this study is that pregnant women with a history of KEK experience difficulty in childbirth, although the numbers are not too significant, this of course still has to be a concern, especially how to prevent pregnant women from experiencing anemia, and if it has occurred as a midwife, of course they must be able to detecting impending complications by performing an early screening of labor
\end{abstract}

Keywords: Childbirth, Chronic Energy Deficiency (KEK) 


\section{PENDAHULUAN}

Kekurangan Energi Kronis (KEK) merupakan suatu kondisi yang harus diwaspadai oleh setiap ibu hamil. Kondisi ini bisa terjadi pada wanita usia subur yaitu perempuan direntang usia 15-45 tahun. Organisasi Kesehatan Dunia World Health Organization $(W H O)$ melaporkan bahwa prevalensi anemia dan KEK pada kehamilan global 35-75 \% dimana secara bermakna tinggi pada trimester ketiga dibandingkan trimester pertama dan kedua kehamilan. WHO juga mencatat $40 \%$ kematian ibu di negara berkembang berkaitan dengan anemia dan KEK dengan prevalensi terbanyak dari kasus tersebut karena KEK (Riskesdas, 2018).

Ibu hamil yang mengalami KEK akan mengalami kekurangan gizi, tubuh mudah lelah, pucat, lemas, dan mengalami kesulitan salah satunya dalam proses persalinan. Pengaruh KEK terhadap proses persalinan dapat mengakibatkan persalinan sulit dan lama, persalinan sebelum waktunya (prematur), pendarahan setelah persalinan, serta persalinan dengan operasi (Proverawati, dkk, 2010: 50).

Penelitian yang dilakukan oleh Suryati, 2014. Tentang Faktor-faktor yang mempengaruhi kejadian premature, hasil penelitian: Anemia waktu hamil pada kasus $82,9 \%$ pada kontrol 37,1\%; KEK pada kasus $64,1 \%$ pada kontrol 10,3\%; jarak kehamilan berisiko pada kasus 45,6\% pada kontrol $23,1 \%$; punya riwayat penyakit berisiko pada kasus $12,8 \%$ dan pada kontrol 17,9\%. Hasil analisis bivariat ada hubungan KEK (Kurang Energi Krinik) $(\mathrm{p}=0,000)$, anemia $(\mathrm{p}=0,000)$,
KEK $(p=0,000)$ dan jarak kehamilan $(\mathrm{p}=0,005)$ dengan persalinan Prematur. Riwayat penyakit yang diderita ibu selama hamil seperti: Hipertensi, Preeklampsi, Eklampsi, Anemia, Dibetes Mellitus dan penyakit khronik lainnya dapat berdampak pada kehamilan dan janin yang dikandungnya, seperti abortus, persalinan prematur dan BBLR. Pada penelitian persalinan premature dapat dipengaruhi oleh KEK pada masa kehamilan sehingga penyakit yang diderita tersebut berpengaruh terhadap kejadian persalinan Prematur (Suryati, 2014).

Angka Kejadian KEK di Kabupaten Ciamis berdasarkan Profil kesehatan Kabupaten Ciamis ibu hamil kurang energi kronis sebesar 18,2\% (Profil Kesehatan Dinas Kesehatan Kabupaten Ciamis, 2016). Berdasarkan hasil laporan dari Puskesmas Sadananya tahun 2019 bahwa ibu hamil yang ada di wilayah kerja puskesmas sadananya mengalami beberapa penyulit selama masa kehamilan yang diantaranya terjadinya Kurang Energi Kronis (KEK) selama masa kehamilan dan terjadiya Anemia pada ibu hamil. Angka kejadian KEK pada ibu hamil di tahun 2017 total ibu hamil yang mengalami KEK sebanyak 72 orang, mengalami peningkatan pada tahun 2018 sebanyak 75 orang kasus KEK (Dinas Kesehatan, 2020)

Penelitian ini bertujuan untuk mengetahui gambaran persalinan pada ibu dengan riwayat kekurangan energi kronis (KEK) pada masa kehamilan 


\section{METODE PENELITIAN}

Jenis penelitian yang digunakan dalam penelitian ini adalah jenis penelitian deskriptif, yaitu penelitian yang memberikan gambaran persalinan pada ibu dengan riwayat KEK pada masa kehamilan. Populasi dalam penelitian ini adalah seluruh ibu bersalin dengan riwayat KEK pada masa kehamilan di Wilayah Kerja Puskesmas Sadananya Kabupaten Ciamis Tahun 2019 sebanyak 70 orang. Pengambilan sampel dengan cara total sampling.

\section{HASIL PENELITIAN DAN}

PEMBAHASAN

\section{Hasil Penelitian}

1. Kejadian Persalinan Lama Pada Ibu KEK

\begin{tabular}{lcc} 
Persalinan Lama & f & $\mathbf{\%}$ \\
\hline Ya & 0 & 0 \\
Tidak & 70 & 100 \\
\hline \multicolumn{1}{c}{ Total } & $\mathbf{7 0}$ & $\mathbf{1 0 0}$
\end{tabular}

Berdasarkan tabel diatas dapat dilihat bahwa dari 70 Responden, diketahui bahwa sebagian proses persalinan tidak mengalami persalinan lama $70(100 \%)$

\section{Persalinan Sebelum Waktunya Pada} Ibu KEK

Persalinan

\begin{tabular}{|c|c|c|}
\hline $\begin{array}{c}\text { Sebelum } \\
\text { Waktunya }\end{array}$ & f & $\%$ \\
\hline Ya & 3 & 4,3 \\
\hline Tidak & 67 & 95,7 \\
\hline
\end{tabular}

Berdasarkan tabel di atas diketahui responden yang mengalami persalinan sebelum waktunya sebanyak 3 orang $(4,3 \%)$ dan kurang dari setengahnya responden mengalami proses persalinan normal sebanyak 67 orang $(95,7 \%)$
3. Perdarahan Setelah Persalinan Pada Ibu KEK

\begin{tabular}{|c|c|c|c|}
\hline $\begin{array}{l}\text { Perdarahan } \\
\text { Persalinan }\end{array}$ & Setelah & f & $\%$ \\
\hline Retensio Plasenta & & 0 & 0 \\
\hline Atonia Uteri & & 1 & 1,4 \\
\hline Repture Parenium & & 0 & 0 \\
\hline $\begin{array}{l}\text { Tidak mengalami } \\
\text { perdarahan }\end{array}$ & & 69 & 98,6 \\
\hline
\end{tabular}

Berdasarkan tabel di atas diketahui responden yang mengalami perdarahan Atonia Uteri sebanyak 1 orang $(1,4 \%)$ dan sebagian besar responden tidak mengalami perdarahan sebanyak 69 orang $(98,6 \%)$.

\section{Persalinan Dengan Operasi Pada Ibu KEK}

\begin{tabular}{lcc}
$\begin{array}{c}\text { Persalinan } \\
\text { Dengan } \\
\text { Operasi }\end{array}$ & f & \% \\
\hline Ya & 8 & 11,4 \\
Tidak & 62 & 88,6 \\
\hline \multicolumn{1}{c}{ Total } & $\mathbf{7 0}$ & $\mathbf{1 0 0}$
\end{tabular}

Berdasarkan tabel di atas diketahui responden yang menjalani proses persalinan dengan operasi sebanyak 8 orang $(11,4 \%)$ dan sebagian besar responden menjalani proses persalinan normal sebanyak 62 orang $(88,6 \%)$

\section{Pembahasan}

Berdasarkan hasil penelitian diatas pada penelitian ini, ibu dengan Kurang Energi Kronis (KEK) tidak terdapat ibu yang mengalami persalinan lama, akan tetapi komplikasi persalinan yang dialami ibu dalam penelitian ini misal nya persalinan dengan tindakan, persalinan prematur, dan 
juga terdapat ibu dengan riwayat KEK mengalami perdarahan pasca persalinan.

Lama partus normal bervariasi. Juga tidak tepat karena waktu permulaan persalinan seringkali sukar untuk ditentukan secara tepat. Walaupun demikian, dengan mempertimbangkan masalah ini kita dapat mengatakan bahwa sekitar $60 \%$ dari pasien primigravida dapat diharapkan melahirkan dalam 12 jam, dan lebih dari $85 \%$ pada pasien multipara. Gambaran ini memberi pedoman mengenai perpanjangan persalinan. Jika pada pasien normal persalinan tidak terjadi dalam waktu ini, maka pengiriman ke perawatan konsulen harus dipertimbangkan dengan serius (Wulan. dkk, 2016).

Penyebab terjadinya partus lama, tunggal atau banyak. Sejauh ini penyebab yang paling sering adalah aksi uterus yang tidak efektif; hal ini dapat merupakan satusatunya kelainan atau dapat dikaitkan dengan yang lain seperti disproporsi atau presentasi abnormal (Lubis Z. 2013).

Bila ibu mengalami risiko KEK selama hamil akan menimbulkan masalah, baik pada ibu maupun janin. KEK pada ibu hamil dapat menyebabkan resiko dan komplikasi pada ibu antara lain: anemia, pendarahan, berat badan ibu tidak bertambah secara normal, dan terkena penyakit infeksi. Pengaruh KEK terhadap proses persalinan dapat mengakibatkan persalinan sulit dan lama, persalinan sebelum waktunya (prematur), pendarahan setelah persalinan, serta persalinan dengan operasi cenderung meningkat (Wulan. dkk, 2016).

Berdasarkan hasil penelitian diatas masih terdapat ibu yang mengalami persalinan sebelum waktunya (prematur) pada ibu yang memiliki riwayat Kurang Energi Kronis (KEK), hal ini dapat juga dipengaruhi jika seseorang yang memiliki kekurangan energy kronik KEK maka ibu akan mengalami kekurangan nutrisi baik ibu dan juga bayi, sehingga ibu beresiko terjadinnya persalinan premature (Wulan. dkk, 2016).

Kurang Energi Kronis (KEK) adalah akibat dari ketidakseimbangan antara asupan untuk pemenuhan kebutuhan dan pengeluaran energi. Yang sering terjadi adalah adanya ketidakseimbangan pangan secara musiman atau secara kronis di tingkat rumah tangga, distribusi di dalam rumah tangga yang tidak proporsional, dan beratnya beban kerja ibu hamil. Selain itu, beberapa hal penting yang berkaitan dengan status gizi seorang ibu adalah kehamilan pada usia muda kurang dari 20 tahun, kehamilan dengan jarak yang pendek dengan kehamilan sebelumnya, kehamilan terlalu sering, serta kehamilan pada usia terlalu tua diatas 35 tahun.

KEK ibu hamil dapat mempengaruhi proses pertumbuhan janin dan dapat menimbulkan keguguran, abortus, bayi lahir mati, kematian neonatal, cacat bawaan, anemia pada bayi, asfiksia intra partum (mati dalam kandungan), lahir dengan berat badan lahir rendah (BBLR). Bila BBLR bayi mempunyai resiko kematian, gizi kurang, gangguan pertumbuhan, dan gangguan perkembangan anak.

Penelitian ini ditunjang oleh penelitian yang dilakukan oleh Yuli Kusumawati tentang Faktor-faktor resiko yang berpengaruh terhadap persalinan dengan 
tindakan di dr.Moewardi Surakarta Semarang. dengan jumlah sempel 170 orang, dengan hasil penelitian terdapat hubungan persalinan dengan tindakan dengan status gizi ibu hamil.

Dari hasil penelitian diatas didapatkan bahwa sebagian besar tidak mengalami perdarahan, namun masih ada ibu yang memiliki riwayat KEK mengalami perdarahan, dari bebrapa penelitian dan juga jurnal menyebutkan bahwa riwayat gizi ibu hamil atau KEK dapat membuat ibu mengalami komplikasi pasca salin seperti perdarahan (Rahmi, 2014).

Dari hasil penelitian diatas diketahui sebagian besar ibu mengalami persalinan normal, akan tetapi masih ada ibu yang menjalani proses persalinan dengan operasi sebanyak 8 orang $(11,4 \%)$ pada ibu yang mengalami riwayat KEK, hal ini dikarenakan ibu yang mengalami atau memiliki riwayat KEK, apabila ibu KEK pada ibu hamil dapat menyebabkan risiko terjadnya anemia, pendarahan, berat badan ibu tidak bertambah secara normal, terkena penyakit infeksi, dan menjadi penyebab tidak langsung kematian ibu.5 Sedangkan pengaruh KEK terhadap proses persalinan dapat mengakibatkan persali-nan sulit dan lama, persalinan prematur iminen (PPI), pendarahan post partum, serta peningkatan tindakan sectio caesaria.

\section{SIMPULAN}

Ibu hamil yang mengalami KEK diketahui mengalami persalinan sebelum waktunya sebanyak 3 orang $(4,3 \%)$. Ibu hamil yang mengalami KEK diketahui mengalami perdarahan paska salin disebabkan oleh atonia uteri senabyak 1 orang $(1,4 \%)$. Ibu hamil yang mengalami KEK diketahui mengalami persalinan secara SC sebanyak 8 orang $(11,4 \%)$

\section{DAFTAR PUSTAKA}

Riskesdas, (2018). Kementrian Kesehatan RI, Pusat Data dan Informasi (Pusdatin) Jakarta: Kementrian Kesehatan

Proverawati, dkk. (2010). Atikah Proverawati dan Cahyo Ismawati. Berat Badan Lahir Rendah (BBLR). Yogyakarta: Nuha Medika; 2010

Suryati. (2014). Jurnal Penelitian Tentang Faktor-faktor yang mempengaruhi kejadian premature. Kediri.

Dinas Kesehatan (2020). Puskesmas Sadananya

Wulan, D. R., Susanti, A. I. and Sari, P. (2016) 'Luaran Maternal dan Neonatal pada Ibu Bersalin dengan Riwayat Kekurangan Energi Kronik di Wilayah Kecamatan Jatinangor Tahun 2015 Maternal and Neonatal Outcomes of Women Giving Birth with a History of', 2, pp. 79-83

Lubis Z. (2013). Status gizi ibu hamil serta pengaruhnya terhadap bayi yang dilahirkan. Bogor: Institut Pertanian Bogor.

Rahmi (2014). Faktor-faktor yang Berhubungan dengan Kekurangan Energi Kronik pada Ibu Hamil di Puskesmas Belimbing Padang. Jurnal Kesehatan Medika Saintika. Volume 8 Nomor 1 
Widya Maya Ningrum \& Erni Puspitasari 